Sunday Olayinka Oyedepo*, Theophilus Uwoghiren, Philip Olufemi Babalola, Stephen C. Nwanya, Oluwaseun Kilanko, Richard Olufemi Leramo, Abraham K Aworinde, Tunde Adekeye, Joseph A. Oyebanji, and Olatunde A. Abidakun

\title{
Assessment of Decentralized Electricity Production from Hybrid Renewable Energy Sources for Sustainable Energy Development in Nigeria
}

https://doi.org/10.1515/eng-2019-0009

Received November 21, 2017; accepted April 3, 2018
Keywords: Hybrid system, solar radiation, wind speed, sustainable development, decentralized energy system

\section{Introduction}

\subsection{Background}

Increasing energy access is recognized as an absolute priority for the development of rural and semi- urban areas. For instance, electrification can be achieved via the extension of the grid or increasingly via decentralized generation, more and more frequently with a mix of technologies including renewable energy technologies (RETs) [1].

The challenge of producing sufficient energy to meet the ever increasing global energy consumption, the rapidly depleting fossil fuel reserves, and the serious environmental problems associated with the use of fossil fuels have motivated considerable research attention on clean energy sources. The tendency to use renewable energy resources has grown continuously over the past few decades, be it due to fear over warnings of global warming or because of the depletion of fossil fuels [2, 3].

In recent years, much emphasis has been placed on renewable energy as a viable alternative to engine genera-

\footnotetext{
^Corresponding Author: Sunday Olayinka Oyedepo: Covenant University Ota, Ogun, Nigeria, E-mail:

sunday.oyedepo@covenantuniversity.edu.ng

Theophilus Uwoghiren, Philip Olufemi Babalola, Oluwaseun Kilanko, Richard Olufemi Leramo, Abraham K Aworinde, Tunde Adekeye: Covenant University, Ota, Ogun, Nigeria

Stephen C. Nwanya: University of Nigeria Nssuka, Nigeria Joseph A. Oyebanji: Bells University of Science and Technology Olatunde A. Abidakun: West Virginia University, Evansdale Campus , Morgantown, WV, 26506, USA
} 
tors for remote power production. The effectiveness of this alternative is met when more than one type of renewable energy source such as photovoltaic (PV), wind, biomass, or small-hydroelectric power systems are combined together with energy storage sub-system in order to ensure steady plant power $[4,5]$.

Among the various technologies for green energy generation in the literature, wind and solar energy are commonly used because they are both technically and environmentally viable options [6]. In addition, they are ubiquitous and freely available. The wind and solar energy are freely available and environmental friendly. The hybrid energy system is becoming widespread as it combines different energy sources to maximize each source's strengths, while compensating for the others' shortcomings [7]. The combined utilization of these renewable energy sources are therefore becoming increasingly attractive and are being widely used as alternative of oil-produced energy. Economic aspects of these renewable energy technologies are sufficiently promising to include them for rising power generation capability in developing countries. A renewable hybrid energy system consists of two or more energy sources, a power conditioning equipment, a controller and an optional energy storage system [8].

Hybrid energy systems are not only economical and environmentally benign, but also capable of offsetting the problems with the stochastic fluctuations in climate parameters. They seem to be potentially beneficial for remote locations where conventional fuel supplies are not available or affordable [9].

Despite the abundant availability of renewable energy resources (solar, wind, small and large hydros etc.), Nigeria is characterized with deprivation from conventional energy, arising from poor supply of infrastructure. About $18 \%$ only of the rural population have access to electricity (Sunday, 2011). Where conventional energy is available, its supply is unreliable. Electricity consumption in the country stood at just $137 \mathrm{kWh}$ per head in 2007 [10]. At $137 \mathrm{kWh}$ per capita, electricity consumption is one of the lowest in the world. This possibly might have been responsible for the slow rate of development in the country. This low electricity consumption in Nigeria is primarily due to irregular and inadequate electricity generation and production which leads to less than half of the entire Nigerian population to have access to electricity and only about $18 \%$ of rural population of the country have access to electricity [11].

This scenario can be improved by using the solar and wind energy resources to supplement electricity generation in Nigeria. However, due to intermittent nature of these resources, they may not be suitable and reliable as stand-alone energy conversion systems. Therefore, integration of both renewable energy conversion systems with diesel generator and storage facility could be a reliable energy system in most rural areas in Nigeria.

Utilization of solar and wind power has become increasingly significant, attractive and cost-effective, since the oil crises of early 1970s [12]. However, common drawback with solar and wind energy is their unpredictable nature. In general, the variations of solar and wind energy do not match with the time distribution of demand [13]. The independent use of both the systems results in considerable over-sizing for system reliability, which in turn makes the design costly. As the advantages of solar and wind energy systems became widely known, system designers are now looking for their integration. In this scenario Hybrid Solar Wind Power System (HSWPS) can be considered as a viable option for the energy market especially in Nigeria.

Hybrid energy system is one of the currently most explored techniques for power generation. This technique focuses on the generation of power from two different energy sources and it has proven to solve the power crisis in many countries around the world to a very large extent. The development and utilization of such a hybrid system will enhance the reduction lower major health risks through the air, land and water pollution. Adverse effects of global warming on weather and climate can be mitigated by reduced $\mathrm{CO} 2$ emissions. As a result, there will be reduction in health care costs and the impact of likely stricter federal emission standards in the future.

Hybrid power systems can consist of any combination of wind, photovoltaics, diesel, small hydropower and batteries. Such flexibility has obvious advantages for customizing a system to a particular site's energy resources, costs, and load requirements.

The potential of solar and wind hybrid energy has been analyzed in literature and several designs of the hybrid energy systems have been proposed: Nema, et al [8] analyzed the current situation in the design, operation and management of independent hybrid solar PV-wind energy systems. They also analyzed the future development of these systems, as well as the potential for increasing the economic viability of these systems and their acceptance by the users. They proposed two systems: self-hybrid system and a system that in the absence of electricity uses excess energy which has been previously stored.

Utilization of solar and wind power has become increasingly significant, attractive and cost-effective, since the oil crises of early 1970s [12]. However, common drawback with solar and wind energy is their unpredictable nature. In general, the variations of solar and wind energy do not match with the time distribution of demand [13]. 
The independent use of both the systems results in considerable over-sizing for system reliability, which in turn makes the design costly. As the advantages of solar and wind energy systems became widely known, system designers have started looking for their integration. In this scenario Hybrid Solar Wind Power System (HSWPS) can be considered as a viable option for the energy market especially in Nigeria.

Hybrid energy system is one of the currently most explored techniques for power generation. This technique focuses on the generation of power from two different energy sources and it has proven to solve the power crisis in many countries around the world to a very large extent. The development and utilization of such a hybrid system will enhance the reduction in major health risks through reduced air, land and water pollution. Adverse effects of global warming on weather and climate can be mitigated by reduced $\mathrm{CO}_{2}$ emissions. As a result, there will be decrease in health care costs and the impact of likely stricter federal emission standards in the future.

Hybrid power systems can consist of any combination of wind, photovoltaics, diesel, small hydropower and batteries. Such flexibility has obvious advantages for customizing a system to a particular site's energy resources, costs, and load requirements.

Salwan and Sopian [14] proposed a PV/Wind system that would provide enough electricity for a settlement in rural areas. Barsoum and Goh [15] described the design, simulation and feasibility study of a hybrid energy system for a standalone power system. This analysis was based on TRNSYS software. The result of this study was a design of a realistic hydrogen energy system that maximizes the renewable energy penetration and minimizes the diesel fuel consumption. Shakya et al. [16] presented the results of the technical feasibility and the financial analysis of a hybrid wind-photovoltaic system with hydrogen storage. Mahmoudi [17] investigated the weather data (hourly wind speed and daily solar radiation) for hybrid power system (HPS) in arid coastal countries. The study assessed the feasibility of using HPS in the Arabian Gulf country of Oman. Zoulias and Lymberopoulos [18] investigated a techno-economic analysis of the integration of hydrogen energy technologies in renewable energybased stand-alone power systems using HOMER simulation tool. The experimental result shows that the replacement of fossil fuel based generator-sets with hydrogen technologies is technically feasible and economically favorable compared to the PV-diesel system as long as a 50\% reduction on the cost of electrolysers and a $40 \%$ reduction on the cost of hydrogen tanks are made. Kaiser and Aditya [19] developed a model using HOMER simulation tool to find out the best technically viable renewable based energy system for the consumers located in Saint Martin Island, Bangladesh. Experimental results showed that it will be better to create PV-wind mini-grid combination system for 50 homes instead of single home system. Ghassan and Johnson [20] examined the capacity and potential for electricity-generating solar- and wind-turbines installed in the Eastern and Northern part of Jordan. The results showed that the cost of windmill farm to produce 100-150 MW was US $\$ 290$ million while solar power station to produce $100 \mathrm{MW}$ costs US $\$ 560$ million. The electrical power costs US $\$ 0.02 / \mathrm{kWh}$ for the wind power and US $\$ 0.077$ for the solar power. The feasibility for using wind and solar energies is now when the price oil reaches US $\$ 100.00$ per barrel. Ghassan [21] investigated the electrical and power calculations for solar and wind utilization to support the national grid in Jordan. The result showed that the cost for the windmill farm to produce 100-150 MW for 20 hours per day is US $\$ 290$ million. The cost of the solar power station to produce $100 \mathrm{MW}$ for 8 hours per day is US\$560 million. The production cost per kWh (in US cents) was 2 cents for the windmill and 7.7 cents for the solar. The conventional production cost 9.5 cents projected when the price of oil was $\$ 100$ per barrel. The study concluded that for reliable energy system, hybrid power production is essential. Nwosu and Agu [4] presented power and energy balance in a wind-solar hybrid power system having battery and combined heat and power (CHP) sub-units as backups. The result of the study showed that it is possible to guarantee steady availability by power plants given proper combinations of wind and solar energy sources with backups to compensate for source fluctuations. Since, in the absence of enough power from the stochastic sources, the battery backup temporarily assumes a status of a power source in the context of global energy balance. CHP is the alternative power source if the battery state of charge (SOC) is below a set point or if the absence of the stochastic sources persists over a certain period of time. The authors concluded that although the optimization case study was conducted in a winter-summer environment, the scheme promises to be more energy productive in a temperate African environment as ninety-five per cent of the daily global sunshine above $6.5 \mathrm{kWh} / \mathrm{m}^{2}$ falls on Africa during the winter. Ajao et al. [22], discussed details description of the Hybrid Optimization Model for Electric Renewables (HOMER) model and confirmed the potential power of Solar-wind Hybrid systems for Small scale Production in Nigeria. 


\subsection{Renewable Energy Resources in Nigeria}

Renewable energy plays a vital role in meeting the needs of both rural and urban areas of the country in terms of sustainable development [23]. The development and proper use of renewable energy should be given high priority, especially now that the issues of climate change and global warming are among the most critical issues discussed by the various governments of the world. Developed and developing countries are now adopting renewables in order to achieve energy sustainability [24].

Clean and environmental friendly energy can only be achieved through the proper utilization of renewable energy technology [25]. The renewable energy resources in Nigeria are as enormous as they are diverse. However, the problem lies with the level of utilization which is very low. Renewable energy technology has great potentials in alleviating the staggering energy situation currently being experienced in Nigeria. Nigeria is endowed with huge amount of both conventional and renewable energy resources. The potentials of renewable energy resources in Nigeria is about 1.5 times that of conventional energy resources in energy terms.

Nigeria has abundant reserves of renewable energy sources ranging from solar, hydro, wind to biomass, etc. It is derived from non-fossil and non-nuclear sources in ways that can be replenished while its harvesting, conversion and use occur in a way that helps to avoid negative impacts on the viability and rights of local communities and natural ecosystems. Apart from the non-replenishment of the abundant fossil fuels that are present in the country, there is also the great threat to global climate through the release of carbon dioxide, heavy metals and particulates.

In view of this, the country must focus on the development of renewable and sustainable sources. Sustainable energy development in Nigeria is the key to the stability of the country, in terms of viable economy, social order and political stability.

Many indigenous researchers have investigated the availability of renewable energy resources in Nigeria with a view to establishing their viability in the country [26-30].

Among all the renewable energy resources available, solar is the most promising of them all due to its apparent limitless potentials. Nigeria is located within a high sunshine belt and solar radiation is well distributed within the country. The intensity of solar radiation exhibits remarkable variation from the northern region to the southern region but is higher in the northern region as shown in Figure 1.

According to Bekele and Palm [31], the tropical regions offer a better solar energy resource than at more temper- ate latitudes. The average annual irradiation in Europe is about $1000 \mathrm{kWh} / \mathrm{m}^{2}$, while in the Middle East the value is approximately $1800 \mathrm{kWh} / \mathrm{m}^{2}$. In the tropical zone, of which Nigeria is a part, the average annual irradiation is estimated to be around $1934.5 \mathrm{kWh} / \mathrm{m}^{2}$. (For future reference it might be easier if these units were expressed as $\mathrm{kWh} \mathrm{m}-2$ ) The annual average of total solar radiation varies from about $12.6 \mathrm{MJ} / \mathrm{m}^{2}$-day $\left(3.5 \mathrm{kWh} / \mathrm{m}^{2}\right.$-day) in the coastal latitudes to about $25.2 \mathrm{MJ} / \mathrm{m}^{2}$-day $\left(7.0 \mathrm{kWh} / \mathrm{m}^{2}\right.$ day) in the far north. This gives an average annual solar energy intensity of $1934.5 \mathrm{kWh} / \mathrm{m}^{2}$-yr; thus over the course of a year, an average of 6,372,613 PJ/year (circa 1,770 thousand TWh/year) of solar energy falls on the entire land area of Nigeria. This is about 120 thousand times the total annual average electrical energy generated by the Power Holding Company Nigeria Plc (PHCN). With a 10\% conservative conversion efficiency, the available solar energy resource is about 23 times the Energy Commission of Nigeria's $(\mathrm{ECN})$ projection of total final energy demand for Nigeria in the year 2030 [32]. This gives us an impression that implementing solar energy strategy is a great opportunity for Nigeria to get renewable energy at low cost as well as minimize dependence from fossil fuels; and finally solar energy would give an opportunity to implement infrastructure where before it seemed to be too hard or too expensive.

During the day it is estimated that Nigeria receives about $4.851 \times 10^{1} 2 \mathrm{kWh}$ of energy from the sun. All this energy is equivalent to about 1.082 million tons of oil per day, while domestic consumption of oil is 297 thousand barrels per day. When we change barrels into tones we see very exiting numbers; 297000 barrels $=47219.2281$ tons $=$ 0.0472192281 million tons. Theoretically (and most likely practically as well) it is obviously seen that domestic demand for oil can be substituted by solar energy [33].

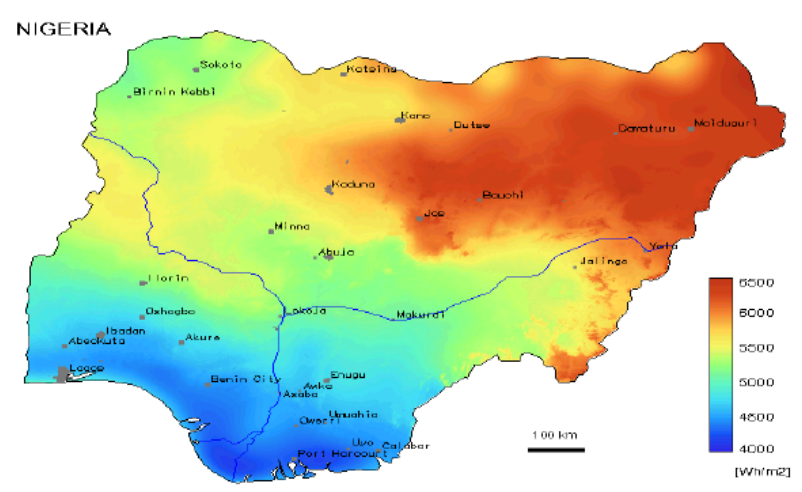

Figure 1: Solar Radiation Map of Nigeria [32] 
On the potentials for wind-to-electricity projects in Nigeria, a number of study reports exist. A study on the wind energy potentials for a number of Nigerian cities shows that the annual average speeds of about $2.2 \mathrm{~m} / \mathrm{s}$ at the coastal region and $4.5 \mathrm{~m} / \mathrm{s}$ at the far northern region of the country. With an air density of $1.1 \mathrm{~kg} / \mathrm{m}^{3}$, the wind energy intensity perpendicular to the wind direction ranges between $4.4 \mathrm{~W} / \mathrm{m}^{2}$ at the coastal areas and $35.2 \mathrm{~W} / \mathrm{m}^{2}$ at the far northern region [34, 35].

Further study on the wind resources in Nigeria revealed that the North, Central and South-East of the nation possess enormous potential for harvesting wind energy, with possible wind speeds reaching as high as $8.70 \mathrm{~m} / \mathrm{s}$ in the north [36]. Thus, latest results (NIMET,2009) based on the outcome of using 40 years (1968-2007) available average wind data from the whole forty-four wind stations across the states of the federation showed that, the country's wind regime is found to lie majorly between poor to moderate regimes, with the southern states having their mean wind profile at $10 \mathrm{~m}$ height in the range between 3.0 $-3.5 \mathrm{~m} / \mathrm{s}$, depending on the states, and Northern states capable with mean wind speeds of between $4.0-7.5 \mathrm{~m} / \mathrm{s}$. This means that, Nigeria has good wind resources over most part of the country. Although, wind speeds in the southern states are low, they can however be employed for standalone power generating systems using small scale wind turbines. This if employed, will be a major breakthrough for rural and sub-rural areas not connected to national electricity grid.

At present, the share of wind energy in the national energy consumption has remained on the lower end with no commercial wind power plants connected to the national grid. Only a few number of stand-alone wind power plants were installed in the early 1960s in 5 northern states mainly to power water pumps and a $5 \mathrm{~kW}$ wind electricity conversion system for village electrification installed at Sayyan Gidan Gada, in Sokoto State [37]. In recent times, numerous studies have been carried out to assess the wind speed characteristics and associated wind energy potentials in different locations in Nigeria. Promising attempts are being made in Sokoto Energy Research Centre (SERC) and Abubakar Tafawa Balewa University, Bauchi, to develop capability for the production of wind energy technologies.

Indigenous researches revealed that Nigerian's Hydro Potential is high and hydropower currently accounts for over $32 \%$ of the total installed commercial electric power capacity. The overall large-scale potential (exploitable) is in excess of 11,000 MW [38].

Nigeria has considerable hydro potential sources exemplified by her large rivers, small rivers and stream and the various river basin being developed. Nigerian rivers distributed all over the country with potential sites for hydropower scheme which can serve the urban, rural and isolated communities. An estimation of river Kaduna, Benue and Cross River (at Shiroro, Makurdi and Ikom respectively) indicated that total capacity of about 4,650 MW is available, while the estimate for the river Mambilla plateau is put at 2,330 MW [39]. Total capacity of the untapped hydropower potential sites identified by Motor Columbus in the 1970 s was $7322 \mathrm{MW}$.

Studies have shown that SHP potential sites exist in virtually all parts of Nigeria. There are over 278 unexploited sites with total potentials of 734.3 MW [40]. So far about eight (8) small hydropower stations with aggregate capacity of 37.0 MW have been installed in Nigeria by private company and the government. Indeed small-scale (both micro and mini) hydropower systems possess the advantage, over large hydro systems, that problems of topography are not excessive [41]. In effect, small hydropower systems can be set up in all parts of the country so that the potential energy in the large network of rivers can be tapped and converted to electrical energy. In this way the nation's rural electrification projects can be greatly enhanced.

\subsection{The Rationale for Decentralized Electricity Generation with RETs in Nigeria}

The rural areas are generally inaccessible due to absence of good road networks, even with the ongoing power reform and privatization of the electricity industry in Nigeria; it is obvious that for logistic and economic reasons, rural areas which are remote from the grid and/or have low power purchase potential will not be attractive to private power investors. Meanwhile electricity is required for basic developmental services as well as economic growth. The absence of reliable energy supply has left the rural populace socially backward and their economic potentials untapped [38].

Energy needs in rural areas are often smaller than in urban areas. For example giving farmers in rural areas access even to small supplies of electricity to charge a mobile phone (which is now a strategic tool for them to get information and sell their crops) can make a huge difference. Larger supplies can power devices related to farming activity, such as water pumping, irrigation; other RETs like the use of passive solar thermal products can be used also for cold/dry chain for preservation/processing of crops [42]. 
The cost of RETs may still be perceived as high, but costs have been decreasing recently making them in more and more instances competitive with stand-alone conventional generation; when a socio-economic lifecycle comparison is made, costs of RETs-generated energy services can be now in rural areas lower than with traditional or conventional energies. This is even more the case when the local environmental and social benefits of RETs are taken into account, as RETs generate less pollution and contribute to the creation of more local jobs than conventional energies [43]. Furthermore, RETs allow for more flexibility than the extension of the grid, as systems can be installed and upgraded according to the needs of users. RETs are attractive because their output matches the low electricity demand levels in rural areas, and enable the avoidance of costly distribution and transmission networks. They also avoid disruptions linked to the unreliable transport of fossil fuel and access to parts in remote areas.

In addition, as the fuel cost is unstable, transportation and restoration of costs for remote places is an additional challenge. To overcome some of these shortcomings of diesel only energy system, integration of renewable energy conversion systems with diesel generators (hybrid energy system) provides a suitable approach to meet the electricity demands in an environmental-friendly way. Therefore, a power supply being both cost-efficient and reliable is necessary for rural areas.

\subsection{Scope and Objectives of the Study}

Having access to sustainable, modern, affordable and reliable energy services is an essential prerequisite for poverty reduction and sustainable socio economic development. Availability of energy services in any region affects all facets of human lives. Hence, lack of these energy services limit the socioeconomic activities that could happen in such environment. Globally, the potential to provide electricity, heat and transport fuels to deliver all Energy services from renewable energies is huge [44]. The available resources are more than sufficient to meet and surpass the entire human energy demand of the present time and the nearest future.

In view of the above facts about significant of renewable energies in achieving sustainable energy, this study aims at (i) assessing the technological feasibility and economic viability of utilizing solar - wind hybrid energy system in the selected locations in Nigeria (ii) analyzing the cost benefit of a solar-wind power hybrid system and determine the pay-back period when compared to cost per kilowatt of utility power supply using HOMER model and (iii) enumerating strategies to adopt towards achieving sustainable energy in Nigeria.

This study is significant not only in providing information to help the government and policy makers in rural energy planning framework but also serves as input data in the design of an appropriate electrification system for use in rural and semi-urban homes or households in Nigeria.

\section{Materials and Methods}

\subsection{Meteorological Data Generation for Feasibility Study}

The development and performance of a hybrid energy system depends on the availability and magnitude of the renewable energy resources. Weather data (wind speed and solar radiation) are important factors for pre-feasibility study of renewable hybrid energy system for any site [11, 45]. The design of PV-wind hybrid system involves the determination of optimum values for the wind turbine's rated power, PV array peak power and storage capacity (and sometimes also the engine generator characteristics) that meet the required reliability conditions for the system. In the following sections, a brief presentation of both solar and wind renewable energy sources in the selected locations is given before some consideration of the optimal sizing of such a hybrid system is presented.

Generally this type of study is heavily dependent on both primary and secondary data, and particularly data from the energy users. Hence, two types of data were used in this study: the primary data for the energy resources and the secondary data for the costs of PV modules, wind turbine, generators, the power ratings of converters and battery and electrical appliances.

The twenty-one years (1992-2012) daily wind speed data, monthly mean daily sunshine duration, maximum air temperature, cloud cover, and maximum relative humidity that were employed for this study were sourced from the Archives of the Nigerian Meteorological agency (NIMET), Oshodi, Lagos. The solar radiation data utilized for the selected sites were derived from solar model proposed by [46] due to insufficient data for the sites. The study focused on designing for 500 rural households in the selected locations in Nigeria. The geographical coordinates of the selected sites are as shown in Table 1.

Among the commonly used methods of hybrid system optimization techniques, the HOMER software has been chosen to be used for the analysis. HOMER (Hybrid Optimization Model for Electrical Renewables) is a user- 
Table 1: The Geographical Coordinates of the Selected Sites

\begin{tabular}{cccccc}
\hline S/No & Geopolitical Zone & Sites & Latitude $\left({ }^{\circ} \mathrm{N}\right)$ & Longitude $\left({ }^{\circ} \mathrm{E}\right)$ & Elevation above sea Level $(\mathrm{m})$ \\
\hline 1 & North Central (NC) & Abuja & 9.27 & 7.03 & 305.00 \\
2 & North West (NW) & Kano & 12.05 & 8.53 & 472.14 \\
3 & North East (NE) & Maiduguri & 11.85 & 13.08 & 383.80 \\
4 & South West (SW) & Abeokuta & 7.25 & 3.42 & 150 \\
5 & South East (SE) & Enugu & 6.47 & 7.55 & 141.5 \\
6 & South South (SS) & Warri & 5.52 & 5.73 & 6.1 \\
\hline
\end{tabular}

friendly micro-power design tool developed in 1992 by the National Renewable Energy Laboratory in the USA [47]. It is primarily an optimization software package which simulates varied renewable energy sources (RES) system configurations and scales them on the basis of net present cost (NPC) which is the total cost of installing and operating the system over its lifetime [48]. HOMER calculates the net present cost of each component of the system, and of the system as a whole.

HOMER allows for comparison with various design options, which makes it easier to assess the techno-economic benefits of different power system configurations. As a result, the software is widely used for the design and simulation of micro-power systems [36, 49].

Using HOMER software, the main input data include the hourly mean wind speed, hourly total solar radiation and load data. In the solar resource window, monthly averaged daily solar radiation data, location and time zones are defined which are used by the software to calculate the hourly incident solar radiation on the PV panel. In the wind resource window, monthly averaged wind speed data, altitude, anemometer height, variation with height, Weibull k, autocorrelation factors, diurnal pattern strength, hour of peak wind speed are defined which are used by HOMER to estimate the wind distribution and output power. Technical specifications and cost data of diesel generators, wind turbines, photovoltaic modules, power converters; system controls; economic parameters; and system constraints are also fed into the simulation program [50].

\subsection{Load Calculation}

Deciding on the load is one of the most important steps in the design of a hybrid system [51]. The household in the remote area in Nigeria is assumed to be simple, not requiring large quantities of electrical energy. In the current study, a rural community of 500 households is considered and the electrical load includes: demand for cooling (ceiling fan), entertaining (television) and lighting.

In accordance to sustainable development policies, energy efficient appliance have been considered in this study [52]. The major electricity end use in rural communities comprises lighting, entertaining and cooling. For this study, this load includes 3 energy efficient lamps (compact fluorescent bulb, $15 \mathrm{~W}$ each), 2 fans (ceiling fan, $40 \mathrm{~W}$ each) and 1 television (TV, $80 \mathrm{~W}$ ) for each household. Day lighting hours do not vary significantly throughout the year in Nigeria. It is normal to experience up to twelve hours of visible light from about 6.00 am to $18.00 \mathrm{pm}$ all year round. In Nigeria, there is an average of 9 hours of sunshine daily, all year round. Therefore, the average number of indoor artificial lighting hours is assumed to be 6.8 hours each day. On weekdays, the family members are usually out of home, so fans are used mostly on hot weekends in the afternoon. Average TV operating time is $5.5 \mathrm{~h}$ per day. Average electric load demand of a typical household is shown in Table 2.

From Table 2, the total consumption per household is averaged at $0.986 \mathrm{kWh} /$ day. The daily average demand for the whole community considered is $20.5 \mathrm{~kW}$ with a peak load of $100 \mathrm{~kW}$ and a load factor of 0.205 . Results of the daily electricity appliance use log suggest that there is very little difference between the daily electricity demand patterns for weekdays and weekends. Day-to-day and timestep-to-time-step variability factors are $15 \%$ and $20 \%$, respectively. The average primary load is calculated to be $1884 \mathrm{kWh} /$ day. It is assumed that this load is constant around the year. The corresponding daily load profile and monthly load profile are presented in Figures 2 and 3.

While the afore-mentioned electric loads are considered as the primary loads (electricity demand that must be met immediately it arises) a second load type is also considered - the deferrable load. It is met only after the primary load has been satisfied except under critical conditions. The deferrable load includes activities like pumping water, charging batteries and fly wheels and heating water. Due to the nature of the load, it also determines the energy storage capacity of a system. The storage capacity can be 
Table 2: Average Electric load Demand of a typical household

\begin{tabular}{llll}
\hline Appliance and Quantity & Power (kW) & Average Usage (Hours/day) & $\begin{array}{l}\text { Consumption } \\
(\mathrm{kWh} / \text { day })\end{array}$ \\
\hline Lights (CFL) (3) & 0.045 & 6.8 & 0.306 \\
Fan (2) & 0.08 & 3 & 0.24 \\
TV (1) & 0.08 & 5.5 & 0.44 \\
\hline Total & & & 0.986 \\
\hline
\end{tabular}

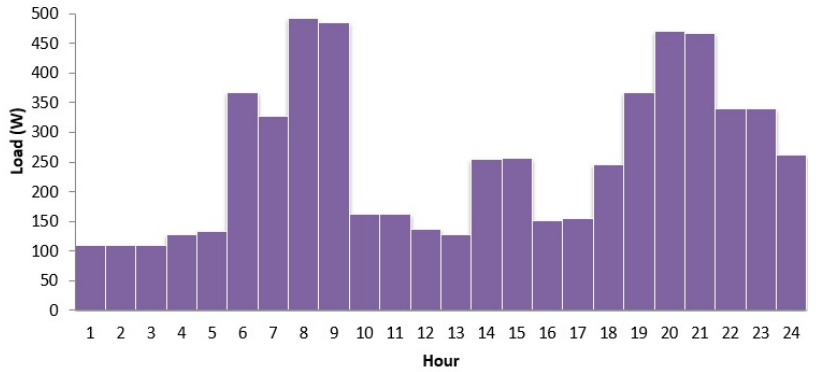

Figure 2: Daily Load Profile

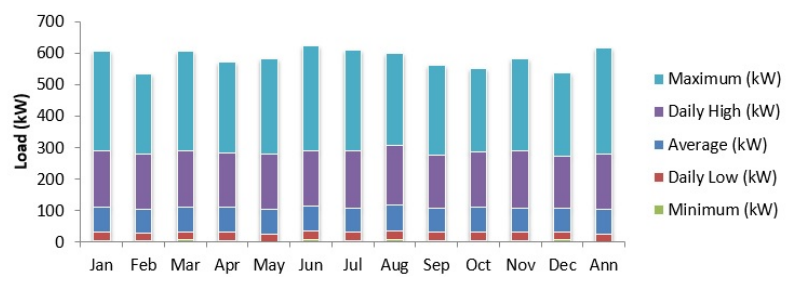

Figure 3: Seasonal load profile

described as the amount of electricity required to fully satisfy the deferrable load. In this system, the deferrable load is the pump used in pumping of water into tanks available and the storage capacity is the amount of electricity required to fill it.

For the 500 households, a minimum of 50,000 litres of water per day is required (i.e 100 liter per family). To accomplish this, 14 pumps of $150 \mathrm{~W}$ with a pumping capacity of $10 \mathrm{l} / \mathrm{min}$ operating for $6 \mathrm{~h} /$ day are assumed. The peak deferrable load is $2.1 \mathrm{~kW}$ and the average deferrable load is calculated to be $12.6 \mathrm{kWh} /$ day. Assuming a water storage capacity of 4 days, the corresponding electricity storage capacity is $50.4 \mathrm{kWh}$. The total daily energy consumption for the community of 500 families is therefore the sum total of the primary load and the deferrable load, which adds up to $1886 \mathrm{kWh}$. The monthly deferrable load is presented in Figure 4.

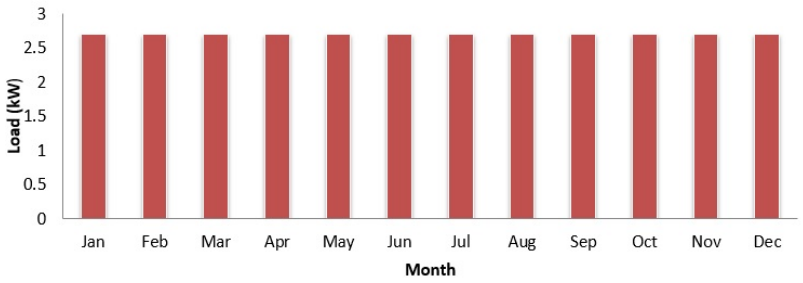

Figure 4: Monthly Deferrable Load

\subsection{Hybrid Energy System Model}

In the present study, a Wind-PV-Diesel hybrid power system and a power converter is used to design and meet the load requirements of the selected locations under investigation. The schematic diagram of the Wind-PV-Diesel hybrid model used in this study is presented in Figure 5. The hybrid power system optimization tool [47] developed by NREL has been used in the present study and the details of the same are given in next paragraph.

In order to predict the hybrid system performance, individual components need to be modeled first and then their mix can be evaluated to meet the load demand. The methodology for modeling hybrid PV/wind system components is described below.

\subsubsection{Design of the Photovoltaic (PV) System}

Solar energy is harnessed through the conversion of sunlight into electricity through the use of solar cells in solar panel. This system is called Photovoltaic (PV) system [53]. In solar energy conversion system, knowledge of global solar radiation is extremely important for the optimal design and forecasting of the system's performance. In PV conversion, the range of useful wavelengths is between 0.35 and $1.1 \mu \mathrm{m}$ for a silicon PV cell but, generally, global solar irradiation is measured in its entire spectrum for PV system studies (using a pyranometer or silicon irradiance sensor) [54].

In this section the mathematical model for sizing stand-alone PV system which comprises of the PV mod- 


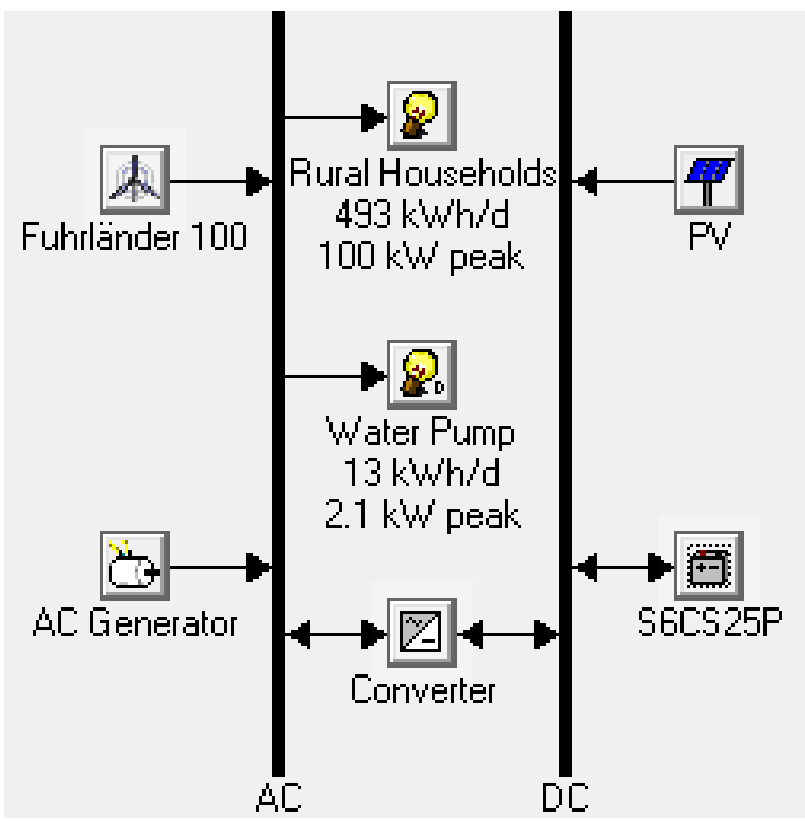

Figure 5: Wind-PV-Diesel Generator Hybrid Model Used in the Study

ules, the storage battery, the battery charger controller and the inverter are explained.

To design a stand-alone PV system for the considered household, the following steps are required.

\subsubsection{Solar Radiation Estimation from Sunshine Duration Data}

Nigeria is one of the developing countries without properly recorded solar radiation data and, like many other countries, what is available is sunshine duration data. However, given a knowledge of the number of sunshine hours and local atmospheric conditions, sunshine duration data can be used to estimate monthly average solar radiation, with the help of empirical equation [55]:

$$
H=H_{o}\left(a+b \frac{\bar{n}}{\bar{N}}\right)
$$

Where, $\mathrm{H}$ is the monthly average daily radiation on a horizontal surface $\left(\mathrm{MJ} / \mathrm{m}^{2}\right) ; \mathrm{H}_{o}$ is the monthly average daily extraterrestrial radiation on a horizontal surface $\left(\mathrm{MJ} / \mathrm{m}^{2}\right)$; $\bar{n}$ is the monthly average daily number of hours of bright sunshine; $\bar{N}$ is the monthly average of the maximum possible daily hours of bright sunshine (i.e the day length of the average day of the month); $a$ and $b$ are regression coefficients which can be obtained using the following equations for M number of data points:

$$
a=\frac{\sum \frac{H}{H_{0}} \sum\left(\frac{\bar{n}}{\bar{N}}\right)^{2}-\sum \frac{\bar{n}}{\bar{N}} \sum \frac{\bar{n}}{\bar{N}} \cdot \frac{H}{H_{o}}}{M \sum\left(\frac{\bar{n}}{\bar{N}}\right)^{2}-\left(\sum \frac{\bar{n}}{\bar{N}}\right)^{2}}
$$

$$
b=\frac{M \sum \frac{\bar{n}}{\bar{N}} \frac{H}{H_{o}}-\sum \frac{\bar{n}}{\bar{N}} \sum \frac{H}{H_{o}}}{M \sum\left(\frac{\bar{n}}{\bar{N}}\right)^{2}-\left(\sum \frac{\bar{n}}{\bar{N}}\right)^{2}}
$$

Solar radiation known as extraterrestrial radiation, Ho, on a horizontal plane outside the atmosphere is given as:

$$
\begin{aligned}
& H_{o}=\frac{24 \times 3600 \times G_{s c}}{\pi}\left(1+0.033 \times \operatorname{Cos}\left(\frac{360 \cdot n_{d}}{365}\right)\right) \\
& x\left(\operatorname{Cos} \varnothing \operatorname{Cos} \sigma \operatorname{Cos} w_{s}+\frac{2 \pi \cdot w_{s}}{360} \operatorname{Sin} \varnothing \operatorname{Sin} \sigma\right)
\end{aligned}
$$

Where, $\mathrm{n}_{d}$ is the day number; $\mathrm{G}_{s c}$ is the solar constant $=1367 \mathrm{M} / \mathrm{m}^{2} ; \varnothing$ is the latitude of the location; $\sigma$ is the declination angle and it is given as $\sigma=$ 23.45 $\operatorname{Sin}\left(360 . \frac{248+n_{d}}{365}\right) ; \mathrm{w}_{s}$ is the sunset hour angle and it is given as: $w_{s}=\operatorname{Cos}^{-1}(-\tan \varnothing \tan \sigma)$.

The maximum possible sunshine duration $\mathrm{N}$ is given by:

$$
N=\frac{2}{15} w_{s}
$$

Equations (1) to (5) are used to calculate the extraterrestrial radiation and the maximum possible daily hours of bright sunshine, respectively at the specific location.

\subsubsection{Calculation of diffuse solar radiation $\left(\mathrm{H}_{d}\right)$}

The diffuse solar radiation $\mathrm{H}_{d}$ can be estimated by an empirical formula which correlates the diffuse solar radiation component $\mathrm{H}_{d}$ to the daily total radiation $\mathrm{H}$. In this study, the monthly average daily diffuse radiation $\mathrm{H}_{d}$ is calculated from monthly average daily global radiation using the Erbs et al. correlation [55]. Equations for these correlations are as follows: For $w_{s} \leq 81.4^{\circ}$ and $0.3 \leq \bar{K}_{T} \leq 0.8$

$$
\frac{\bar{H}_{d}}{\bar{H}}=1.391-3.560 \bar{K}_{T}+4.189 \bar{K}_{T}^{2}-2.137 \bar{K}_{T}^{3}
$$

and for $w_{s}>81.4^{\circ}$ and $0.3 \leq \bar{K}_{T} \leq 0.8$

$$
\frac{\bar{H}_{d}}{\bar{H}}=1.311-3.022 \bar{K}_{T}+3.427 \bar{K}_{T}^{2}-1.821 \bar{K}_{T}^{3}
$$

Where $\bar{K}_{T}=\frac{H}{H_{o}}$ is clearness index

\subsubsection{Total Irradiated Energy Arriving at an Inclined Surface}

For a good sizing, we need to have hourly data of tilted global solar irradiations because the PV modules are placed at any slope angle, then horizontal solar radiations data must be converted into tilted ones. The sum total of 
direct beam radiation, diffuse radiation and ground reflection radiation equals irradiation $\mathrm{H}_{G}$ for the entirety of an inclined surface [56]:

$$
H_{G}=H_{G B}+H_{G D}+H_{G R}=R_{B} \cdot\left(H-H_{D}\right)+R_{D} \cdot \rho \cdot H
$$

Where $\mathrm{H}$ is irradiation from global radiation on the horizontal plane; $\mathrm{H}_{D}$ is irradiation from diffuse radiation on the horizontal plane; $\mathrm{R}_{B}=\frac{\operatorname{Cos} \theta}{\operatorname{Cos} \theta_{z}}$ is direct beam radiation factor (the ratio of beam radiation on the PV array to that on the horizontal); $\mathrm{R}_{D}=\frac{1}{2}+\frac{1}{2} \cos \beta$ is diffuse radiation factor; $\mathrm{R}_{R}$ $=\frac{1}{2}-\frac{1}{2} \cos \beta$ is effective portion of reflective radiation; $\beta$ is inclination angle of the inclined surface relative to the horizontal plane; $\rho$ is reflection factor (albedo) of the ground in front of the solar generator; $\theta$ is the incidence angle of beam irradiance on the array and $\theta z$ is the zenith angle of the sun.

\subsubsection{Power Calculation of Solar PV Panel}

With the available solar energy resource as discussed above, the corresponding power that can be harnessed using solar PV panel is calculated thus $[57,58]$ :

$$
P_{P V}(t)=H_{G}(t) \cdot A_{P V} \cdot \eta_{P V}
$$

Where $\mathrm{P}_{p v}(\mathrm{t})$ is the power output from the PV-panel (W), $\mathrm{H}_{G}(\mathrm{t})$ is the total solar irradiance data at time $\mathrm{t}\left(\mathrm{W} / \mathrm{m}^{2}\right), \mathrm{A}_{p v}$ is the area of a single PV-panel $\left(\mathrm{m}^{2}\right)$ and $\eta_{p v}$ represents the PV generator efficiency and is given by Kolhe et al. [59]:

$$
\eta_{P V}=\eta_{r} \cdot \eta_{P C}\left[1-\mu\left(\theta_{\text {cell }}-\theta_{\text {cell }, r e f}\right)\right]
$$

where $\eta_{r}$ is the reference module efficiency, $\eta_{p c}$ is the power conditioning efficiency which is equal to 1 if a perfect maximum power tracker (MPPT) is used. $\mu$ is the generator efficiency temperature coefficient. For silicon cells the range of $\mu$ is 0.004 to 0.006 per $\left({ }^{\circ} \mathrm{C}\right), \eta_{\text {cell, ref }}$ is the reference cell temperature $\left({ }^{\circ} \mathrm{C}\right)$ and $\eta_{\text {cell }}$ is the cell temperature $\left({ }^{\circ} \mathrm{C}\right)$ and can be calculated as follows [60]:

$$
\theta_{\text {cell }}=\theta_{a}+\left[\frac{N O C T-20}{800}\right] \times H_{G}(t)
$$

where $\theta_{a}$ is the ambient temperature $\left({ }^{\circ} \mathrm{C}\right)$ and NOCT is the nominal cell operating temperature $\left({ }^{\circ} \mathrm{C}\right) . \eta_{p c}, \mu$, NOCT and $\mathrm{A}_{P V}$, are parameters that depend upon the type of module used. The data are obtained from the PV module manufacturers.

The number of modules that can produce the required amount of solar energy can be estimated as [61]:

$$
N_{m}=\frac{P_{p v(t)}}{S_{\text {peak-power }}}
$$

where $S_{\text {peakpower }}$ is the peak power of the selected PV module and it is provided in the manufacturer's data sheet.

\section{Sizing of the Battery Performance}

Due to its advantages of a low-cost, maintenance-free and highly efficient technology, Lead-acid batteries are usually used for energy storage in hybrid systems to store surplus energy, to regulate system voltage and to supply load in case of insufficient solar radiation and/or wind.

Battery capacity depends on maximum depth of discharge (DOD), temperature and age [62, 63].

As for the sizing of the battery, the storage capacity of the battery can be calculated according to the following relation [61]:

$$
M_{\text {batt }}=\frac{A_{d} \times D_{L}}{\eta_{B C H} \times \eta_{i n v} \times D O D \times V_{s}}
$$

where $\mathrm{A}_{d}$ is maximum number of continuous cloudy day, DoD is maximum permissible depth of discharge of the battery, $\mathrm{D}_{L}$ is the daily energy demand and $\mathrm{V}_{s}$ is the system voltage which are usually in $12,24,48, \ldots \mathrm{V}$.

The number of battery required for the system can be determined using the following equation [61]:

$$
n_{\text {batt }}=\frac{M_{\text {batt }}}{M_{\text {sin }}}
$$

where $M_{\sin }$ is the storage capacity of a single battery in (Ah).

The storage capacity of the battery system in Amperehour (Ah) considering the load requirement, the required days of autonomy, allowable depth of discharge, and losses due to inverter and battery charging can be determined using the following relation [64]:

$$
C_{B}=\frac{D_{L} \times t_{a}}{D O D \times \eta_{B} \times \eta_{i n v} \times V_{B}}
$$

where $\mathrm{C}_{B}$ is the battery bank rated capacity (Ah), $t_{a}$ is the designed autonomy(days), DOD is the allowable depth of discharge, and $\mathrm{V}_{B}$ is the voltage of the battery block(V).

\section{Sizing of Inverter}

Power inverter system is required to convert the DC power output to $\mathrm{AC}$ power output in hybrid power system. Hence, any inverter selected must be able to handle the maximum expected ACloads for any of the hour of the day. The cost of a power converter depends on its size and type (either pure sine wave or modified sine wave). The power requirement of the inverter, $\mathrm{P}_{i n v}(\mathrm{~kW})$, is given as [65]:

$$
P_{\text {inv }}=1.25 \times P_{f d}
$$

where $\mathrm{P}_{f d}(\mathrm{~kW})$ is the power demand of the facility. 


\subsubsection{Assessment of Wind Potential}

The energy in the wind is harnessed by utilizing a wind turbine. The energy the wind transfers to the rotor of the wind turbine is proportional to the density of the air, the rotor area, and the cube of the wind speed.

Power output of wind turbine generator at a specific site depends on wind speed at hub height and speed characteristics of the turbine. Wind speed at hub height can be calculated by using power-law equation [66].

$$
\frac{U(H)}{U\left(H_{r e f}\right)}=\left(\frac{H}{H_{r e f}}\right)^{\propto}
$$

where $\mathrm{U}(\mathrm{H})$ and $\mathrm{U}\left(\mathrm{H}_{\text {ref }}\right)$ are the wind speed at hub and reference height $\mathrm{H}$ and $\mathrm{H}_{r e f}$ and a is roughness coefficient. The value of the coefficient varies from less than 0.10 for very flat land, water or ice to more than 0.25 for heavily forested landscapes (Danish, 2008). The one-seventh power law (0.14) is a good reference number for relatively flat surfaces such as the open terrain of grasslands away from tall trees or buildings.

From the average hourly wind speed profile, if the wind speed is between the cut-in speed and the rated speed of the wind turbine, the power output of a wind energy conversion system (ECS) $\mathrm{P}_{W}(\mathrm{U})$ can be calculated as follows [67]:

$$
P_{w}(U)=\frac{1}{2} \rho A U^{3}
$$

Where, $\mathrm{P}_{w}(\mathrm{U})$ is the Output power of the wind turbine $(\mathrm{W})$, $\rho$ is the density of the air, A is the Rotor Area (A typical $1,000 \mathrm{~kW}$ wind turbine has a rotor diameter of 54 meters, i.e. a rotor area of some 2,300 square meters) and $U$ is the wind speed $(\mathrm{m} / \mathrm{s})$.

Generally, the cut-in speed of a wind turbine is in the range of $2.5-3.5 \mathrm{~m} / \mathrm{s}$ and cut-out speed is in the range of 20 $-25 \mathrm{~m} / \mathrm{s}$.

\subsubsection{Diesel Generator System}

The fuel consumption of diesel generator is affected by the rated power of the generator and the actual power output. The fuel consumption of the diesel generator $\left(\mathrm{F}_{D G}\right)$ in $(1 / \mathrm{h})$ is given by equation (19)

$$
F_{D G}=A_{1 G} X P_{O G}+A_{2 G} X P_{R G}
$$

Where $\mathrm{P}_{O G}$ and $\mathrm{P}_{R G}$ are the output power and the rated power of the generator in $\mathrm{kW}$, respectively. $\mathrm{A}_{1 G}$ and $\mathrm{A}_{2 \mathbf{G}}$ are the coefficients of the consumption curve in $(1 / \mathrm{kWh})$, where $\mathrm{A}_{1 G}=0.2461 / \mathrm{kWh}$ and $\mathrm{A}_{2 G}=0.08145$ for the diesel generation [68].

\subsubsection{Economic Assessment of Hybrid Energy System (HES)}

The decision whether to accept or reject a HES design for a given location depends on the economic viability and cost of energy. Some of the economic factors methods for appraising HES after the design to determine its suitability are Net Present Value (NPV), Net Present Cost (NPC) and Cost of Energy (COE).

The HOMER software mainly simulates the net present cost (NPC) and cost of energy (COE) of a hybrid energy system. The simulation inputs include the initial capital, replacement cost, and operating and maintenance cost of each component of a HES. NPC means the present value of the costs of investment and operation of a system over its lifetime. NPC is used as a main economic indicator to compare energy systems.

The Net Present Cost of an energy system is a summation of all costs involved in the life cycle of the energy system. The total net present cost comprising of the following costs: capital investment, non-fuel operation and maintenance costs, replacement costs, energy costs (fuel cost plus any associated costs), and any other costs. If a number of options are being considered then the option with the lowest Net Present Cost will be the most favourable financial option. When alternatives have same life expectancy and cost then the only major consideration is the NPC [69]. The NPC can be mathematically written as [47]:

$$
\begin{gathered}
C_{N P C}=C_{O}+C_{r e p}+\sum_{t=1}^{N} \frac{C_{t}}{(1+i)^{t}}-S V C A=C_{N P C} \times C R F \\
C A=C_{N P C} \times C R F
\end{gathered}
$$

where $\mathrm{C}_{N P C}$ is the NPC of an energy system, $\mathrm{C}_{O}$ is the cost of initial investment, $\mathrm{C}_{\text {rep }}$ is the replacement cost (at $t=$ $0), C_{t}$ is the total annualized cost of the system (\$/year), $i$ is the annual real interest rate (\%), $S V$ is the salvage value (at $t=0$ ), and $C R F$ is the Capital Recovery Factor.

The capital recovery factor (CRF) is given by [47]:

$$
C R F=\frac{i(1+i)^{N}}{(1+i)^{N}-1}
$$

Where $N$ is the energy system lifetime and $i$ is the annual interest rate for the energy system lifetime.

Cost of Energy (COE) is the price at which electricity can be generated from a given source to break even. It is an economic assessment of energy generating plant which includes all the costs over its life period such as the initial investment and the operation and maintenance. 
The COE of the system is evaluated as follows [70]:

$$
\operatorname{COE}=\frac{C_{t}}{E_{t}}
$$

Where $\mathrm{C}_{t}$ and $\mathrm{E}_{t}$ are the total annualized cost and total electricity consumption respectively.

In sustainability analysis, smaller values of NPC and COE mean a less payment to match the same electricity load. For achieving a sustainable economic efficiency, it is to minimize these two types of cost.

\section{Results and Discussion}

\subsection{Solar Energy Potential Assessment}

Regarding solar energy potential there is no accurately recorded solar radiation database in the country, instead only sunshine hour data was available. Empirical formulas are used to estimate the solar radiation from available sunshine duration data obtained from the archive of National Aeronautics and Space Administration renewable energy resource - NASA (GEOS-1) Multiyear Time-series Data Website (1992-2012) for all the six locations. The monthly daily averaged global solar radiation for the locations investigated is shown in Figure 6. From Figure 6, the annual averaged daily global solar radiation is $4.93 \mathrm{~kW} / \mathrm{m}^{2}$ day $^{-1}$ in Abeokuta, $5.48 \mathrm{~kW} / \mathrm{m}^{2} \mathrm{day}^{-1}$ in Abuja, $4.96 \mathrm{~kW} / \mathrm{m}^{2}$ day $^{-1}$ in Enugu, $5.92 \mathrm{~kW} / \mathrm{m}^{2}$ day $^{-1}$ in Maiduguri, $5.90 \mathrm{~kW} / \mathrm{m}^{2}$ day $^{-1}$ in Kano and $4.53 \mathrm{~kW} / \mathrm{m}^{2}$ day $^{-1}$ in Warri. The clearness index which is availability of global solar radiation varies with geographical location and period of the year. Clearness index in the cities studied varies from 0.303 to 0.683 . The least clearness index is in Warri (0.303) in the month of July and the highest value is 0.683 in Kano in the month of April.

Figure 6: Monthly average solar radiation at the six investigated locations

\subsection{Wind Energy Potential Assessment}

The wind speed data used in this study were obtained from Nigerian Meteorological Agency (NIMET), Oshodi, Lagos. The wind speed data were captured at $10 \mathrm{~m}$ height by a cupgenerator Anemometer. The monthly mean speed at the investigated locations based on 21years (1992-2012) wind speed data is presented in Figure 7. Figure 7 shows that the monthly wind speed vary between $2.03 \mathrm{~m} / \mathrm{s}$ in January to $2.66 \mathrm{~m} / \mathrm{s}$ in April for Abeokuta; $1.61 \mathrm{~m} / \mathrm{s}$ in October to $3.16 \mathrm{~m} / \mathrm{s}$ in January for Abuja; $1.73 \mathrm{~m} / \mathrm{s}$ in December to $2.41 \mathrm{~m} / \mathrm{s}$ in July for Enugu; $2.75 \mathrm{~m} / \mathrm{s}$ in November to $3.76 \mathrm{~m} / \mathrm{s}$ in February for Kano; $2.22 \mathrm{~m} / \mathrm{s}$ in October to $4.01 \mathrm{~m} / \mathrm{s}$ in March for Maiduguri; $1.73 \mathrm{~m} / \mathrm{s}$ in December to $2.74 \mathrm{~m} / \mathrm{s}$ in July for Warri. The annual mean wind speed and the correspond power density (assumed that air density is $1.225 \mathrm{~kg} / \mathrm{m}^{3}$ ) for each location are determined as: Abeokuta $(2.42 \mathrm{~m} / \mathrm{s}, 8.68 \mathrm{~W} / \mathrm{m} 2)$, Abuja $(2.45 \mathrm{~m} / \mathrm{s}$, $\left.9.01 \mathrm{~W} / \mathrm{m}^{2}\right)$, Enugu $\left(2.35 \mathrm{~m} / \mathrm{s}, 7.95 \mathrm{~W} / \mathrm{m}^{2}\right)$, Kano $(3.45 \mathrm{~m} / \mathrm{s}$, $\left.25.15 \mathrm{~W} / \mathrm{m}^{2}\right)$, Maiduguri $\left(3.52 \mathrm{~m} / \mathrm{s}, 26.71 \mathrm{~W} / \mathrm{m}^{2}\right)$ and Warri $\left(2.31 \mathrm{~m} / \mathrm{s}, 7.55 \mathrm{~W} / \mathrm{m}^{2}\right)$.

Figure 7: Monthly average wind speeds at the six investigated locations

\subsection{System Sizing}

According to Okoye et al. [64], appropriate sizing of standalone hybrid systems involves balancing energy supply and demand in a cost effective manner. Typically, the desired stand-alone hybrid system should be able to produce the electricity to meet the daily load requirement. In the literature, different hybrid system sizing techniques were categorized as intuitive, numerical, analytical and others. Due to their wide applications in design of hybrid energy system, intuitive and numerical simulation methods are employed in this work.

For the solar PV, a two axis tracking system to direct the PV panels towards the sun all year round was considered. The PV had a life time of 25 years, a derating factor of $75 \%$ and a ground reflectance of $40 \%$. The wind turbine chosen was the Fuhrlander 100 manufactured by Fuhrlander AG. It has a rated power of $100 \mathrm{~kW}$, a hub height of $50 \mathrm{~m}$, Rotor diameter $21 \mathrm{~m}$, Distance to blade tip 53.7 $66.7 \mathrm{~m}$, cut in speed $2.5 \mathrm{~m} / \mathrm{s}$ and cut out speed $25 \mathrm{~m} / \mathrm{s}$. The life time of the turbine is 20 years.

The AC Generator chosen, has operating hours of $15000 \mathrm{hrs}$ and a minimum load ratio of $30 \%$ and a diesel fuel of $\$ 1.01$ per litre was used. The Surette 6CS25P battery was used with a nominal capacity and voltage of $1156 \mathrm{Ah}$ and $6 \mathrm{~V}$ respectively. It has a round trip efficiency of $80 \%$ and Minimum state of charge of $40 \%$ with a float life of 12years. The Converter chosen served as both an inverter and a rectifier with the inverter having an efficiency of $90 \%$ 
and a life time of $15 y$ years. The capacity of the rectifier relative to the inverter was $100 \%$ with an efficiency of $85 \%$.

Table 3 presents system sizing for the hybrid power system combination considered in this study.

\subsection{Results of System Simulation and Optimization}

The optimization results are given out in a categorized form which represents feasible system configurations capable of meeting the system load and constraints. The results are displayed in an increasing order of the total net present cost (NPC). A given system type may have many different configurations based on the size combination of constituent elements. The categorized table displays only the most cost effective configuration from each system type as different from the overall optimization table that displays all feasible system configurations (for any possible system type) ranked in their cost effectiveness. From the details of the optimization analysis the following can be observed: size of different components in each system, electric production of each component, capital cost, replacement and operating and maintenance cost of each system, annualized cost, excess and shortage of capacity, cost of energy (COE), renewable fraction, unmet load, consumption of diesel, operating hour and number of starting of diesel generator, life time of generator and battery, throughput of battery and fuel cost. Capacity Shortage, Renewable fraction, Total Net Present Cost (NPC) and Cost of Energy (COE) values have been used as parameters for selecting a given configuration among the many candidates [47].

In this study, simulation was carried out to determine the feasibility of hybrid renewable energy system configuration that best suit the local renewable energy resources of the six selected locations in Nigeria and then estimates the Net Present Cost (NPC) of the hybrid energy system. The NPC is used to compare the economies of various system configurations. The one with the least NPC is considered as the optimal configuration. Figure 8 presents categorized optimization results for Abeokuta as a representation for other locations.

Figure 8 reveals the optimum hybrid renewable energy configuration as the $\mathrm{PV} /$ diesel/battery/converter system configuration setup with no capacity shortage/unmet load having a high renewable penetration fraction of 34\%, COE of $0.700 \$ / \mathrm{kWh}$ and NPC of \$2,370, 131 for Abeokuta. For Abuja, Enugu, Kano, Maiduguri and Warri, the renewable penetration fraction, COE and NPC are 38\%, 0.677\$/kWh and $\$ 2,290,798 ; 34 \%, 0.699 \$ / \mathrm{kWh}$ and $\$ 2,364,412 ; 41 \%$,

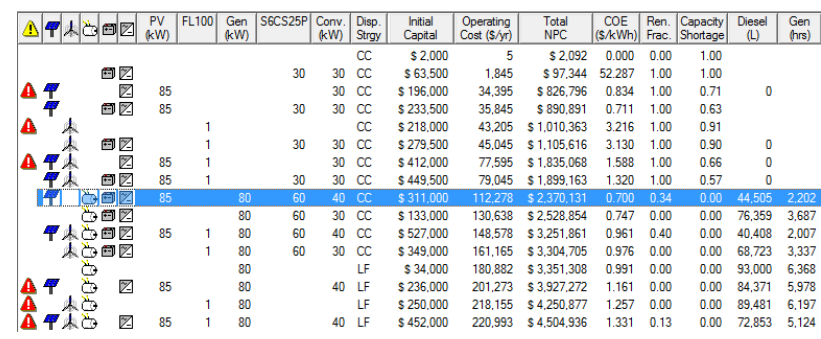

Figure 8: Categorized Optimization Results for Abeokuta

$0.659 \$ / \mathrm{kWh}$ and $\$ 2,230,508 ; 41 \%, 0.658 \$ / \$ / \mathrm{kWh}$ and $\$ 2,225,387$; and 31\%, $0.721 \$ / \mathrm{kWh}$, and $\$ 2,441$, 222, respectively. Based on the results of this study, Kano and Maiduguri have the highest renewable penetration fraction while Warri has the least value of renewable penetration fraction. This is due to disparity in renewable energy resources distribution in the country as presented in Figures 6 and 7. This also responsible for least values of COE and NPC in Maiduguri while Warri has highest values of COE and NPC. The configuration consist of $85 \mathrm{~kW}$ PV system, $80 \mathrm{~kW}$ of AC generator, battery storage of 60 Surrette $6 \mathrm{CS} 25 \mathrm{P}, 40 \mathrm{~kW}$ of inverter and $40 \mathrm{~kW}$ of rectifier. Details result of optimal system configuration for the selected locations are presented in Table 4.

Figure 9 presents cash flow results for Abeokuta as a representation for other locations. Figure 9 shows that the maximum negative cash flow of $\$ 305,000$ occurred at the start of the project. This is expected as all the components of the energy system are purchased at the start of the project. At year $11, \$ 87,000$ is spent replacing the solar panels whose life span is 20 years. At the end of the project life span of 20 years, the component of the system can be sold and a salvage of $\$ 45,000$ is recovered.

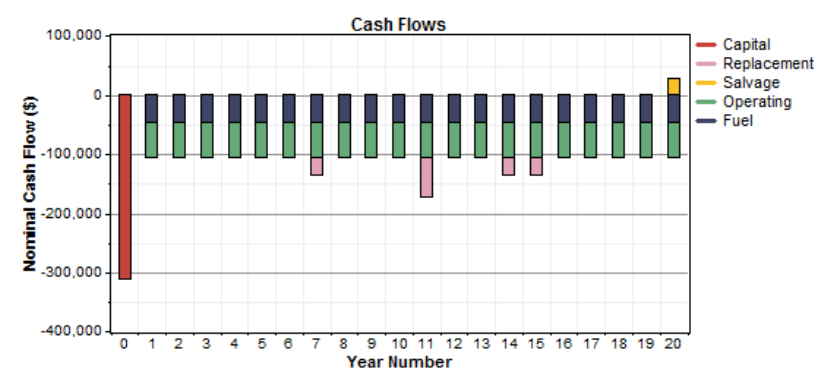

Figure 9: Cash flow for Abeokuta

Figures 10 to 15 show the monthly average amount of electricity generated by each component of the hybrid system in each of the selected locations. AC- Generator denotes the diesel generator and PV the solar-PV in the figures. Critical observation of Figures 10 to 15 shows that the 
Table 3: System Sizing

\begin{tabular}{|c|c|c|c|c|c|c|c|}
\hline Component & Size & Capital & $\begin{array}{l}\text { Replacement } \\
\text { Cost }\end{array}$ & 0\&M Cost & Sized Considered (kW) & $\begin{array}{l}\text { Quantities } \\
\text { Considered }\end{array}$ & Life time \\
\hline PV & 1 & 2000 & 0 & 400 & $\begin{array}{l}0,80,85,90,95,100,105, \\
110\end{array}$ & & 20 years \\
\hline Wind Turbine & 100 & 216000 & 0 & 43200 & & 0,1 & 25 years \\
\hline AC Generator & 1 & 400 & 350 & 0.150 & $\begin{array}{l}0,30,40,50,60,70,80,85 \\
90,95,100,105,110\end{array}$ & & 15000hours \\
\hline Battery & 1 & 1250 & 1100 & $11 \$ /$ year & $\begin{array}{l}0,5,10,15,20,30, \text { strings of } 6 \\
\text { batteries }\end{array}$ & & $9645 \mathrm{kWh}$ \\
\hline Converter & 1 & 800 & 750 & 0 & $\begin{array}{l}0,20,25,30,35,40,4550,60,70, \\
80\end{array}$ & & \\
\hline
\end{tabular}

Table 4: Optimal System Configuration Results for all Locations Showing Cost in Naira (NGN)

\begin{tabular}{|c|c|c|c|c|c|c|}
\hline Location & $\begin{array}{l}\text { Total Net Present } \\
\text { Cost }(\mathrm{N})\end{array}$ & $\begin{array}{l}\text { Operating Cost } \\
\text { (N/yr) }\end{array}$ & $\begin{array}{l}\text { Levelized COE } \\
(\mathrm{N} / \mathrm{kWh})\end{array}$ & $\begin{array}{l}\text { Renewable } \\
\text { Fraction }\end{array}$ & $\begin{array}{l}\text { Diesel } \\
\text { Consumption } \\
(\mathrm{l} / \mathrm{yr})\end{array}$ & $\begin{array}{l}\text { Generator } \\
\text { Operating } \\
(\mathrm{h} / \mathrm{yr})\end{array}$ \\
\hline Abeokuta & $\begin{array}{l}374,717,711 \\
(\$ 2,370,131)\end{array}$ & $\begin{array}{l}17,751,152 \\
(\$ 112,278)\end{array}$ & $\begin{array}{l}110.67 \\
(\$ 0.700)\end{array}$ & 0.34 & 44,505 & 2,202 \\
\hline Abuja & $\begin{array}{l}362,175,164 \\
(\$ 2,290,798)\end{array}$ & $\begin{array}{l}17,067,211 \\
(\$ 107,952)\end{array}$ & $\begin{array}{l}107.03 \\
(\$ 0.677)\end{array}$ & 0.38 & 41,887 & 2,082 \\
\hline Enugu & $\begin{array}{l}373,813,537 \\
(\$ 2,364,412)\end{array}$ & $\begin{array}{l}17,701,825 \\
(\$ 111,966)\end{array}$ & $\begin{array}{l}110.51 \\
(\$ 0.699)\end{array}$ & 0.35 & 44,336 & 2,193 \\
\hline Maiduguri & $\begin{array}{l}351,833,685 \\
(\$ 2,225,387)\end{array}$ & $\begin{array}{l}16,503,269 \\
(\$ 104,385)\end{array}$ & $\begin{array}{l}104.03 \\
(\$ 0.658)\end{array}$ & 0.41 & 39,719 & 1,986 \\
\hline Kano & $\begin{array}{l}352,643,315 \\
(\$ 2,230,508)\end{array}$ & $\begin{array}{l}16,547,537 \\
(\$ 104,665)\end{array}$ & $\begin{array}{l}104.19 \\
(\$ 0.659)\end{array}$ & 0.41 & 39,859 & 1,995 \\
\hline Warri & $\begin{array}{l}385,957,198 \\
(\$ 2,441,222)\end{array}$ & $\begin{array}{l}18,363,947 \\
(\$ 116,154)\end{array}$ & $\begin{array}{l}113.99 \\
(\$ 0.721)\end{array}$ & 0.31 & 46,784 & 2,316 \\
\hline
\end{tabular}

trend of electricity generation by the solar-PV follow the trend of the monthly averaged solar insolation of Figure 6. In this study, the hybrid system comprises of renewable energy fraction varies from 0.51 to 0.63 with the least fraction occurs in Warri and highest in Kano and Maiduguri. The high renewable energy fraction indicates that in most of the time, the electrical energy requirement of the selected locations could be met with the combination of PV and the battery storage system. The diesel generator only comes up in the remaining time thereby bridging the gap between the load demand and the energy supply.

It can be seen from Figures 10 to 15 that the number of run of generator is higher in the months of June, July, August and September. This is expected as these months fall into the peak of raining season when the cleanness index is low in Nigeria. The global solar irradiation for these months is comparatively low due to the presence of cloud

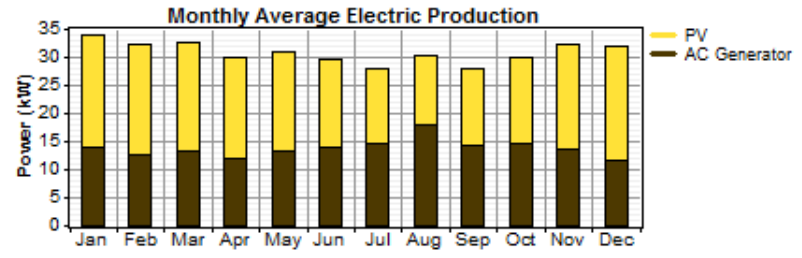

Figure 10: Monthly Average Electric Production for Abeokuta

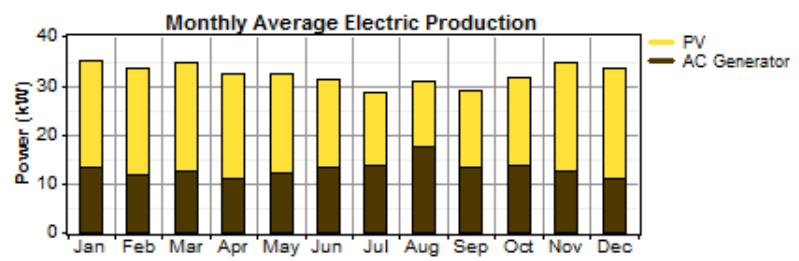

Figure 11: Monthly Average Electric Production for Abuja 


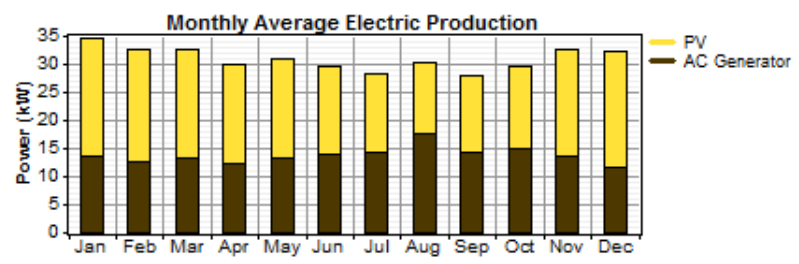

Figure 12: Monthly Average Electric Production for Enugu

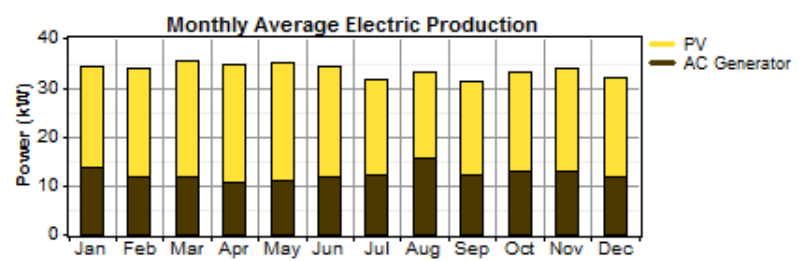

Figure 13: Monthly Average Electric Production for Kano

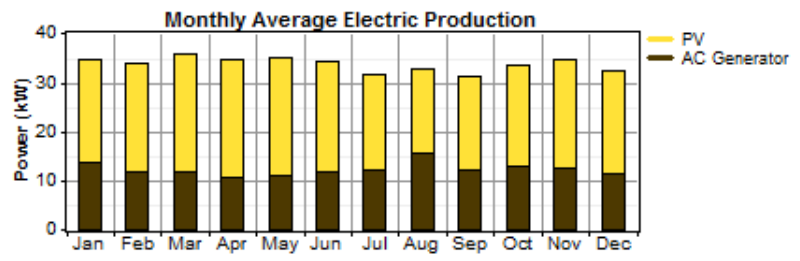

Figure 14: Monthly Average Electric Production for Maiduguri

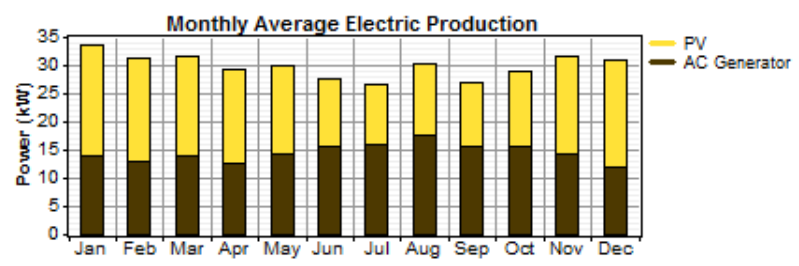

Figure 15: Monthly Average Electric Production for Warri

and therefore results in low electrical output of the PV generator. The months of February, March, April, May and December fall into the peak of dry season with higher sunshine hour, higher clearness index and higher global solar radiation. Consequently, the hour of runs of diesel generator is reduced during these months.

In this study, the simulation analysis shows that the total electricity production $(270,514 \mathrm{kWh} / \mathrm{yr}$, 283, $251 \mathrm{kWh} / \mathrm{yr}, 271,209 \mathrm{kWh} / \mathrm{yr}, 294,247 \mathrm{kWh} / \mathrm{yr}$, 295,113 kWh/yr and 262,257kWh/yr for Abeokuta, Abuja, Enugu, Kano, Maiduguri and Warri, respectively) meet the electrical load $(184,543 \mathrm{kWh} / \mathrm{yr}$ for all the selected locations) by the combination of: 55\% PV and $45 \%$ generator with excess of 85,971 kWh/yr for Abeokuta; $60 \% \mathrm{PV}$ and $40 \%$ generator with excess electricity of 98,708 kWh/yr for Abuja; 55\% PV and 45\% generator with excess electricity of 86,666 kWh/yr for Enugu; 63\% PV and
$37 \%$ generator with excess electricity of $109,704 \mathrm{kWh} / \mathrm{yr}$ for Kano; 63\% PV and 37\% generator with excess electricity of 110,570 kWh/yr for Maiduguri and 51\% PV and $49 \%$ generator with excess electricity of $77.714 \mathrm{kWh} / \mathrm{yr}$ for Warri. The percentage of electricity generation from diesel generator can be reduced if the wind speed for the selected locations can be measured at higher altitude above $10 \mathrm{~m}$ with high wind speed. This would increase renewable fraction in the hybrid system combination. Operating period of the generator can be reduced and hence, less diesel consumption which can result in lower greenhouse gases emission.

\section{Conclusion}

A hybrid power system which consists of diesel Generator set, PV-arrays and wind turbines with energy storing devices (battery bank) and power electronic devices has been studied in this paper to achieve an efficient and cost competitive system configuration so that hybrid power sources could improve the life of people especially in rural areas where electricity from the main grid has not reached yet.

The feasibility study for the hybrid system is based on the findings of the wind and solar energy potentials at six selected locations. From the results, the wind energy potential of all selected sites are not attractive enough for the total electricity demand of $1886 \mathrm{kWh}$ for 500 families. This is as a result of the low wind speed profile recorded at low altitude $10 \mathrm{~m}$ for the selected locations: Abeokuta, Abuja, Enugu, Maiduguri, Kano and Warri having a mean annual wind speed of 2.42, 2.45, 2.35, 3.52, 3.45 and $2.31 \mathrm{~m} / \mathrm{s}$, respectively for the 21 years available data. Based on the available resource, the optimum architecture for electricity generation in the selected locations was determined to be PV/Diesel/Battery hybrid energy system.

Results of this study show a list of possible feasible set-ups according to the NPC. The feasible system selected had the least total NPC of the most viable configurations with $0 \%$ capacity shortage and a renewable penetration fraction higher than the recommended $25 \%$. The System Architecture having 85kW PV, 80kW diesel generator. 60 Surette 6CS25P Battery, 40kW Inverter and 40kW Rectifier were the same for all the selected locations.

For the selected locations, Warri has the highest NPC of $\$ 2,441,222$ ( $\mathrm{N} 385,957,198$ ) while Maiduguri had the least NPC of $\$ 2,225,387$ (N 351,833,685) for the 21 years project lifespan. The COE for Warri is $0.721 \$ / \mathrm{kWh}(\mathrm{N} 113.99 / \mathrm{kWh})$ while that of Maiduguri, Abeokuta Abuja, Enugu and Kano are 0.658\$/kWh (N104.03/kWh), \$0.700 (N110.67), \$0.677 
(N107.03), \$0.699 (N110.51) and \$0.659 (N104.19), respectively. Warri has the least Renewable Fraction of $31 \%$ while Maiduguri and Kano have the highest renewable fraction of $41 \%$.

By using hybrid energy system, access rate to electricity in the rural area of the selected locations where national electricity grid extension could be difficult or expensive to achieve can be increased. As this would bring about constant and reliable electricity supply in the rural areas. The reliable supply of electricity through the hybrid system can improve the standard of living and economic activities of the rural habitants.

\section{References}

[1] Kammen, D. and Kirubi, C (2008), Poverty, energy, and resource use in developing countries - focus on Africa. Annales NewYork Academic Science 1136: pp. 348-357.

[2] Paul, S.S, Oyedepo, S.O and Adaramola, M.S (2012), 'Economic assessment of water pumping systems using wind energy conversion systems in the southern part of Nigeria', Energy Exploration \& Exploitation Volume 30 (1): 1 -18.

[3] Getachew B (2009), 'Study into the Potential and Feasibility of a Standalone Solar- Wind Hybrid Electric Energy Supply System for Application in Ethiopia', Doctoral Thesis, Department of Energy Technology, Royal Institute of Technology, KTH

[4] Nwosu, C.A and Agu, M.U (2009), 'Power and Energy Balance in Wind-Solar Hybrid Power System', The Pacific Journal of Science and Technology, vol. 10, (1): 110 - 116

[5] Sudhakar, R and Painuly, J.P (2004), 'Diffusion of Renewable Energy Technologies - Barriers and Stakeholders' Perspectives', Renewable Energy 29(9),:1431 - 1447.

[6] Zhou, W., Lou, C., Lu, L., Yang, H. (2010), Current status of research on optimum sizing of standalone hybrid solar-wind power generation systems, Applied Energy, 87 (2): 380 - 389.

[7] Klychev, S. I., Mukhammadiev, M. M., Zakhidov, R., Potaenko, K. D. (2007), Technical and economic conditions for creation of combined solar-wind power plants, Applied Energy, 43 (4): $214-217$.

[8] Nema, P; Nema, R.K and Rangnekar, S (2009), 'A current and future state of art development of hybrid energy system using wind and PV-solar: A review', Renewable and Sustainable Energy Reviews 13: 2096-2103

[9] Fazelpour, F, Soltani, N, Shariatzadeh, M and Rosen, M.A (2015), 'Economic Analysis of Standalone Hybrid Energy Systems for Application in Tehran, Iran', Proceedings of $6^{\text {th }}$ International Conference on Hydrogen Production May 3-6, 2015 UOITOshawa, Ontario, Canada, Pp 1 - 10

[10] World Development Indicators (Edition: 2010). http://data.worldbank.org/data./world-developmentindicators/wdi-2010

[11] Adaramola, M.S, 'Feasibility Study of off-grid hybrid energy system for application in Ondo State Nigeria', Journal of Engineering and Applied Sciences, 2012, 7(1): 72 - 78.
[12] Tina, G and Gagliano, S (2008), 'Probability Analysis of Weather Data for Energy Assessment of Hybrid Solar/Wind Power System', $4^{\text {th }}$ IASME/WSEAS International Conference on ENERGY, ENVIRONMENT, ECOSYSTEMS and SUSTAINABLE DEVELOPMENT (EEESD’08), Algarve, Portugal, June 11-13, pp $1-7$

[13] Lin, W., Matsuo, H and Ishizuka, Y (2003), 'Performance characteristics of buck-boost type two-input DC-DC converter with an active voltage clamp' IEICE Technique Report, Vol. 102 ( 567): 7-13.

[14] Salwan S.D and Sopian K (2010), 'Electricity generation of hybrid PV/wind systems in Iraq', Renewable Energy, 35:1303 - 7

[15] Barsoum N. N and Goh W.C (2006), 'Modeling the Feasibility of an Integrated Hydrogen Hybrid Energy System for Stand Alone Power System', Proceeding of Australian universities in power and energy conference AUPEC 06,10 -13 December, Melbourne, Australia.

[16] Shakya B.D, Lu A, and Musgrave P (2005), 'Technical feasibility and financial analysis of hybrid wind-photovoltaic system with hydrogen storage for Cooma', International Journal of Hydrogen Energy, 30:9 - 20

[17] Mahmoudi, H(2008), 'Weather data and analysis of hybrid photovoltaic-wind power generation systems adapted to a seawater greenhouse desalination unit designed for arid coastal countries' Desalination,222(1-3):119-127. http.dx.doi.org/10.1016/j.desal.2007.01.135

[18] Zoulias, E.I and Lymberopoulos, N (2007), “Techno-economic analysis of the integration of hydrogen energy technologies in renewable energy-based stand-alone power systems", Renewable Energy, vol. 32, 680-696

[19] Kaiser, M.S and Aditya, S.K(2006), "Energy efficient system for St Martin Island of Bangladesh", in Proceedings of the Journal of Engineering and Applied Sciences, vol. 1, pp. 93-97

[20] Ghassan H and Johnson A. A (2009), 'Wind-Solar Hybrid Electrical Power Production to Support National Grid: Case Study Jordan' Energy and Power Engineering, 72-80

[21] Ghassan H (2010), 'Wind-Solar Hybrid Electrical Power Generation in Jordan', Jordan Journal of Mechanical and Industrial Engineering, Volume 4, (1): $205-209$.

[22] Ajao, K.R, Oladosu, O.A and O.T. Popoola (2011), “Using HOMER Power Optimization Software for Cost Benefit Analysis of Hybrid-Solar Power Generation Relative to Utility Cost in Nigeria”, IJRRAS, Vol. 7 (1), pp. 96 - 102.

[23] Hui S.C.M. (1997), 'From renewable energy to sustainability: the challenge for Honk Kong', Hong Kong Institution of Engineers,:351-358.

[24] Oyedepo, S.O (2012a), 'Energy and sustainable development in Nigeria: the way forward', Energy, Sustainability and Society, 2 (15): $1-17$

[25] Emodi, V.N, Yusuf, S.D and Boo, K (2014), 'The Necessity of the Development of Standards for Renewable Energy Technologies in Nigeria', Smart Grid and Renewable Energy, 5: 259-274.

[26] Onyebuchi E.I (1989), 'Alternative energy strategies for the developing world's domestic use: A case study of Nigerian household's final use patterns and preferences', The Energy Journal 10(3):121-138

[27] Adekoya LO and Adewale A.A (1992), 'Wind energy potential of Nigeria', Renewable Energy 2(1):35-39.

[28] Ngala G.M, Alkali B and Aji M.A (2007), 'Viability of wind energy as a power generation source in Maiduguri, Borno state, Nige- 
ria', Renewable energy 32 (13):2242-2246.

[29] Akinbami JFK (2001) Renewable Energy Resources and Technologies in Nigeria: Present Situation, Future Prospects and Policy Framework', Mitigation and Adaptation Strategies for Global Change 6:155-181. Kluwer Academic Publishers, Netherlands

[30] Oyedepo, S.O (2012b), 'On energy for sustainable development in Nigeria', Renewable and Sustainable Energy Reviews 16:2583-2598.

[31] Bekele, G and Palm, B (2010), 'Feasibility study for a standalone solar-wind-based hybrid energy system for application in Ethiopia', Applied Energy 87: 487-495

[32] Nwulu, N.I and Agboola, O.P (2011), 'Utilizing Renewable Energy Resources to Solve Nigeria's Electricity Generation Problem', Int. J. of Thermal \& Environmental Engineering Volume 3, No. 1: $15-20$

[33] Energy Commission of Nigeria (ECN)(2005) Renewable Energy Master Plan, Abuja

[34] Sambo, A. S. (2009). Strategic developments in renewable energy in Nigeria. International Association for Energy Economics. 4:15-19.

[35] Akinbulire, T.O, Oluseyi, P.O and Babatunde, O.M (2014), 'Techno-economic and environmental evaluation of demand side management techniques for rural electrification in Ibadan, Nigeria', Int. J Energy Environ Eng. 5(132): 1 - 11.

[36] Ajayi, 0.0 (2009) Assessment of utilization of wind energy resources in Nigeria, Energy Policy, 37, 750-753.

[37] Uzoma, C.C., C.E. Nnaji, C.N. Ibeto, C.G. Okpara, O.O. Nwoke, I.O. Obi and O.U. Oparaku, 2011. Renewable energy penetration in Nigeria: A study of the South-East zone. Continental Journal of Environmental Sciences, 5(1): 1-5.

[38] Oyedepo, S.O (2014), 'Towards achieving energy for sustainable development in Nigeria', Renewable and Sustainable Energy Reviews 34: 255-272

[39] Makoju, J.O (2003), Small Hydro Power Construction: Techno - Economic Analysis', ECN/UNIDO Trainers Workshop on SHP Planning and Development, Owerri, May 2003.

[40] Esan, A.A (2003), 'Preparedness on Development Green Energy for Rural Income Generation-Nigeria's Country Paper', UNIDO, INSHP/IC SHP, Hangzhou, China June 19-23, 2003.

[41] Ajao, K.R, Ajimotokan, H.A, Popoola, O.T and Akande, H.F (2009), 'Electric Energy Supply in Nigeria, Decentralized Energy Approach', New York Science Journal, 2(5): 84 - 92.

[42] Dornan, M (2011), 'Solar-based rural electrification policy design: the renewable energy service company (RESCO) model in Fiji', Renew. Energy 36: pp. 797-803.

[43] del Rıo, P and Burguillo, M (2008), Assessing the impact of renewable energy deployment on local sustainability: Towards a theoretical framework, Renewable and Sustainable Energy Reviews, $12: 1325-1344$

[44] Akinwale, Y.O, Ogundari, I.O, Ilevbare, O.E and Adepoju, A.O (2014), 'A Descriptive Analysis of Public Understanding and Attitudes of Renewable Energy Resources towards Energy Access and Development in Nigeria', International Journal of Energy Economics and Policy, Vol. 4, No. 4: pp.636-646.

[45] Pragya N and Dutta, S (2012), 'Feasibility Study of 1 MW Standalone Hybrid Energy System: For Technical Institutes', Low Carbon Economy, 3, 63-68

[46] Sunday $\mathrm{O}$ (2010), Estimation of global and diffuse solar radiations for selected cities in Nigeria, International Journal of Energy and Environmental Engineering, Vol.2 / No.3, pp.13-33.
[47] HOMER (2013), The micropower optimization model, www.homerenergy.com, May, 2013

[48] Connolly, D, Lund, H, Mathiesen, B.V and Leahy, M (2010), 'A review of computer tools for analyzing the integration of renewable energy into various energy systems', Applied Energy 87: $1059-1082$.

[49] Okundamiya, M.S and Omorogiuwa, O (2015), 'Viability of a Photovoltaic Diesel Battery Hybrid Power System in Nigeria', Iranica Journal of Energy and Environment 6(1): $5-12$

[50] Banos, R, Manzano-Agugliaro, F, Montoya, F.G, Gil, C, Alcayde, A and Gómez, J (2011), 'Optimization methods applied to renewable and sustainable energy: A review', Renewable and Sustainable Energy Reviews 15: 1753 - 1766.

[51] Bekele, G and Boneya, G (2012), ‘Design of a Photovoltaic-Wind Hybrid Power Generation

System for Ethiopian Remote Area', Energy Procedia 14: 1760 1765

[52] Winkler, H (Ed.) (2006), Energy policies for sustainable development in South Africa - Options for the future, Energy Research Centre, University of Cape Town, Private Bag, Rondebosch 7701, South Africa.

[53] Aliyu, A.S, Dada, J.O and Adam, I.K (2015), 'Current status and future prospects of renewable energy in Nigeria', Renewable and Sustainable Energy Reviews 48:336-346.

[54] Kaldellis, J.K (2010), Stand-alone and hybrid wind energy systems Technology, energy storage and applications, Woodhead Publishing Limited, Abington Hall, Granta Park, UK, pp 102 121.

[55] Duffie, J.A and Beckman, W.A (2013), Solar Engineering of Thermal Processes ( $4^{\text {th }}$ Ed.), John Wiley \& Sons, Inc., Hoboken, New Jersey, pp $43-77$.

[56] Heinrich H. (2012), Photovoltaic: System Design and Practice, John Wiley \& Sons, Ltd.,

United Kingdom, pp $65-89$.

[57] Lambert, T Gilman, P and Lilienthal, P (2006), Micropower system modeling with HOMER.

Integration of alternative sources of energy, 15.

[58] Nelson D.B, Nehrir N.H and Wang C (2006), Unit sizing and cost analysis of standalone hybrid wind/PV/fuel cell power generation systems. Renewable Energy, 31:1641 - 56.

[59] Kolhe M, Joshi J.C and Kothari D.P (2004), Performance analysis of a directly coupled photovoltaic water-pumping system, IEEE Trans. On Energy Conversion, 19:613 - 618.

[60] Diaf, S, Notton, G, Belhamel, M, Haddadi, M and A. Louche (2008), "Design and techno-economical optimization for hybrid $\mathrm{PV} /$ wind system under various meteorological conditions," $\mathrm{Ap}$ plied Energy, Vol. 85, No. 10, pp. 968-987.

[61] Ayodele, T.R and Ogunjuyigbe, A.S.O (2015), 'Increasing household solar energy penetration through load partitioning based on quality of life: The case study of Nigeria', Sustainable Cities and Society 18:21-31.

[62] Zhou, W, Yang,H, and Fang, Z (2008), 'Battery behavior prediction and battery working states analysis of a hybrid solar-wind power generation system', Renewable Energy 33:1413-1423

[63] Piller, S, Perrin, M and Jossen, A (2001), 'Methods for state-ofcharge determination and their Applications', Journal of Power Sources 96:113-120

[64] Okoye, C.O, Taylan, 0 and Derek K. Baker, D..K (2016), 'Solar energy potentials in strategically located cities in Nigeria: Review, resource assessment and PV system design', Renewable 
and Sustainable Energy Reviews 55:550 - 566

[65] Oko C.O.C, Diemuodeke E.O, Omunakwe N.F and Nnamdi E (2012) Design and Economic Analysis of a Photovoltaic System: A Case Study. Int. Journal of Renewable Energy Development 1(3): $65-73$

[66] Kaabeche, A, Belhamel, M and Ibtiouen, R (2011), Technoeconomic valuation and optimization of integrated photovoltaic/wind energy conversion system, Solar Energy 85:24072420

[67] Freris, L.L (1990), Wind Energy Conversion Systems, Englewood Cliffs, NJ: Prentice-Hall, $182-184$.
[68] Kenneth E. O, Roland U and Ngang B.N (2015), 'A Comparative Study of on and off Grid Tied Integrated Diesel Solar PV Generation System', International Journal of Engineering Technologies, Vol. 1, No1, pp $19-25$

[69] Nottona, G; Diaf, S and Stoyanov, L (2011), 'Hybrid Photovoltaic/Wind Energy Systems for Remote Locations', Energy Procedia 6: $666-677$

[70] Fazelpour, F, Soltani, N and Rosen, M.A (2014), 'Feasibility of satisfying electrical energy needs with hybrid systems for a medium-size hotel on Kish Island, Iran', Energy 73:856-865. 